\title{
Analysis of the Availability of Healthy Food to Residents of Megalopolis: Who Try to Keep to a Healthy Lifestyle
}

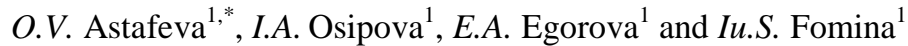 \\ *Corresponding author: astafeva86@mail.ru \\ ${ }^{1}$ Financial University under the Government of the Russian Federation, Moscow, Russia
}

\begin{abstract}
The aim of this work is to assess the state of the markets, healthy nutrition and healthy food delivery in Moscow in order to identify business opportunities for market entry of a new member-the company "GoodFoodFit". Within the designated goals there were set the following objectives: to conduct market analysis of healthy food delivery across Russia and Moscow; to identify the main trends and tendencies of markets; to analyze the key market participants of healthy food deliverers and identify their weaknesses and strengths; to determine the main consumers and their preferences; to identify the business opportunities to create one's own service, and finally to prepare financial justification of the project implementation. As a result of the analysis of the Russian market of healthy eating and the study of consumer preferences of people looking to maintain a healthy lifestyle and utilizing healthy food delivery service, it was revealed that the most promising for creating healthy food delivery service is the average price segment.
\end{abstract}

Keywords: healthy food, healthy eating, the market of healthy eating, consumer preferences, healthy lifestyle, healthy food delivery market.

\section{Introduction}

The global trend of transition to healthy lifestyle is increasingly strengthening its influence on consumer behavior. A healthy lifestyle is becoming not just a consumer trend, but also a status attribute of a person. In the midst of an active lifestyle and a lack of time to modern people, it is especially important to monitor the food and have the ability to generate customized menus based on characteristics of the organism and personal preferences. Therefore, the relevance of healthy food services are nowadays more important than ever, and in the time to come it will continue to grow.

\section{Problem Statement}

Due to permanent employment and emotional and physical stress people can't always abide by correct diet, so the service on delivery of healthy eating is becoming more and more relevant to people nowadays. The market is actively developing, as evidenced by the growing number of people leading an active lifestyle and using this type of service. Food market both healthy and public at large, is actively developing bringing in many new proposals, but young people increasingly prefer healthy food.

\section{Research Questions}

The research questions are:

- analysis of the state and dynamics of the healthy food market and the healthy food delivery market in Moscow, taking into account consumer preferences;

- research of trends of the market of healthy food;

- identification of the main participants of the market of healthy food delivery.

\section{Purpose of the Study}

The aim of the study is evaluate business opportunities for projects on the organization of service on delivery of healthy eating habits. It is also important to justify the feasibility of a new project, taking into account the saturation of the market for the delivery of healthy food. 


\section{Research Methods}

For the methodological basis of the study there were chosen to be the surveys of modern trends in the field of healthy nutrition, the development of global and domestic market delivery of healthy nutrition and so, the key players have been identified. The results of the sociological surveys were used in the work, as well as the methods of synthesis, comparative analysis, quantitative and qualitative analyses, induction, decomposition were applied in the study.

\section{Findings}

\subsection{The study of development dynamics, tendencies, trends in the market of a healthy diet}

Healthy food market began its active development due to the changes in consumer behavior. So, according to the research by «Deloitte» company on the criteria of consumer choice in the market of food, modern humans prefer to focus not only on the already formed product selection criteria such as taste, price, quality, but also on those that are directly related to health. A number of researchers devoted their works to healthy food market research, among them are Cai-Juana S., Ramlib R., Rosshairy Abdul Rahmanb [1], Korytova V.E., Garbuz S.A., Burdin A.G. [2], Loktev K. [3], Maneaa L., Epuranb G. [4], Ragozin V.V., Golubeva T.B. [5], Voronoi A., Manko P., Yakovleva E. [6].

The following are the factors that generate new demand for healthy food in Russia.

1) The incidence of: According to ROSSTAT (FSSS) the data that are represented in Figure 1, the number of people with diseases such as obesity, diabetes, as well as diseases of digestive organs, is on the increase.

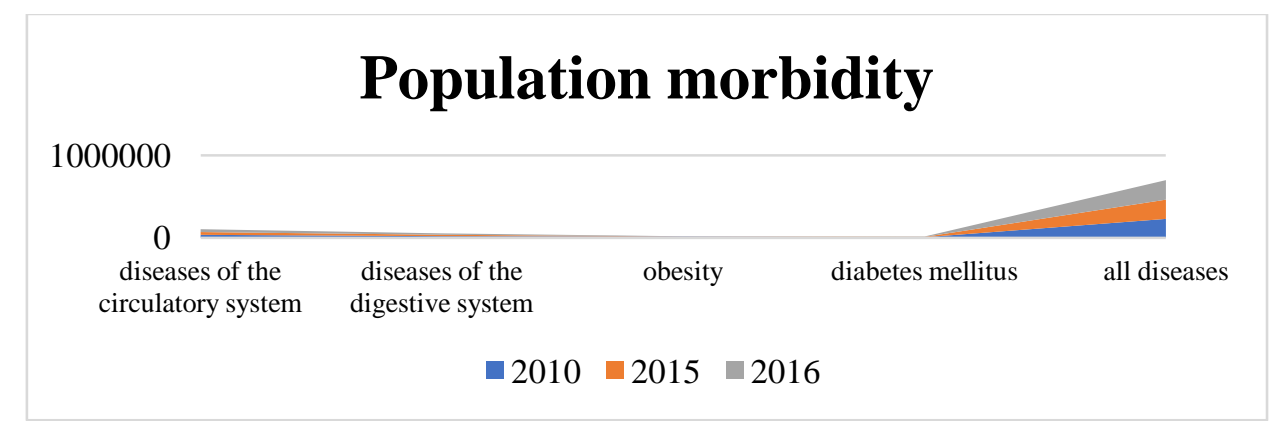

Figure 1. Population morbidity dynamics, thousands people Source: compiled by the authors according to the Rosstat [7]

Poor nutrition is one of the main reasons specified in Figure 1 diseases types. With the aim of preventing these diseases, the inhabitants of Russia are seeking to establish their diets and eat healthy food [1]. According to the Nielsen global study, $70 \%$ of people in the world and $67 \%$ of people in Russia actively monitor their diets to prevent various diseases. About $70 \%$ of consumers both in the world and in Russia are willing to pay more for products that don't contain harmful elements.

2) Healthy lifestyle as an integral part of fashion and status: to be healthy, sporty and active is now fashionable and popular, that is proved by the data of the All-Russian Public Opinion Research Center, according to which over the last 2 years the number of inhabitants of the Russian Federation, involved in sports, grew by $15 \%$. DISCOVERY Research Group research in 2016 discovered that the market volume rose to 874095 million roubles5. According to the experts' forecasts, the annual average rate of increase in this segment will amount to $0.9 \%$. Market volumes indicators from 876690 million roubles in 2017 will change to 912477 million roubles in the year 2021 .

Let's take a look at the trends that can be traced today in the market of healthy eating [3].

1) Craze for the products in the category «health\&wellness». These include the following groups:

- products without: sugar, preservatives, gluten, lactose, artificial colors and flavorings that make the most significant contribution to the development of healthy eating habits. In the year 2016 this market volume grew by $6.8 \%$ and reached USD 36 billion, having become the fastest growing global food market;

- food for vegetarians, vegans and raw food enthusiasts. This trend can be well explained due to the fact that the number of people who have given up on animal products is growing every year. According to the study by Mintel Global Food and Drink Trends 2017, the world has witnessed for the past 4 years, starting from 2012 onwards, an increase by $257 \%$ in the amount of vegan food. In Russia this market is growing annually by an average of $30 \%$. The market volume of the vegetarian products in the year 2016 amounted to RUR 80-100 million [2].

2) «Healthy habits and weight management», or «healthonism и weightmanagement». The trend named «healthonism» - is people's desire to consume healthy foods with familiar taste components. Vivid examples to these are the vegetarian burgers and ice-cream, sweets without sugar, alcohol with antioxidants and the like. "Weightmanagement" is a weight management system. So, there are created a variety of applications where the company communicates directly with the consumer. Via these platforms the manufacturer informs the buyer about the product benefits, its composition, about the way, time and mode of consumption and cooking options. 
Service on delivery of a healthy, balanced diet is widely used and common due to the fact that having modern rhythm of life, people who want to eat right, don't have the time needed to compile the correct menus, let alone to count Calories-Protein-Fat-Carbs in it or cook it. It is estimated that about 20 hours per week could be saved by the people who use services on delivery of healthy eating. According to the company, GrinDin the market of healthy food on a subscription basis, is growing by an average of $20 \%$ per year all over the world. This contributes to the development of logistics systems, technologies, and the increasing popularity of healthy lifestyles. According to the estimates by the research firm Technomic, the world market for food on a subscription basis, which amounted to USD 1 billion in 2015 and by the year 2020 it will rise to 10 billion dollars. Thus, this segment is very attractive for investors, thus it gives the market growth opportunities. In the years 2011-2013 eating on a subscription basis in Russia was booming. According to the experts, the growth of the market is estimated at an average of 5\% per year. The market volume in 2017 amounted to RUR 30-35 million. The total number of service subscribers in Moscow, according to the estimates is about 100-150 thousand people.

Apart from the trends there are a number of additional healthy diet delivery market movements and directions. 1) Improved packages. Market leaders are trying to use the latest technology of gas-modified environment with hermetic sealing and temperature control, which allows you to preserve the freshness of the meals for a few days. 2) Program diversification. On the generation stage of this particular business all the programs were designed in order to achieve athletic results. 3) Providing information on the composition of the meals, the ratio of Calories-Protein-Fats-Carbs, detailed instructions for the consumption of the product (mealtimes, shelf life, way of heating). 4) Creating mobile applications. The process of universal "mobilizing" provides easy ordering, delivering and communicating between the seller and the buyer. 5) High activity on social networks, which is due to the growth of online audience with high purchasing power, and the growth of online retail in general. Thus, we can say that the market for the delivery of healthy food and healthy food market in general are rapidly evolving in modern times, especially in metropolitan areas. This is due to the increased interest among people to a healthy lifestyle, healthy diet, weight loss, and gains of muscle masses, as well as the time constraints on addressing this scope of interests. Nowadays there are a number of factors, trends and tendencies that are conducive to the growth and prosperity of the market, and they are mostly associated with the accelerating pace of life, lack of time for proper nutrition [8].

\subsection{Core market segments of healthy eating and key market players of healthy food delivery in Moscow}

Healthy food delivery market is actively expanding. The number of companies in Moscow with this service, according to the research held by the company «Royal diet» is 40 , that indicates that the market is not saturated and is ready to expand. With regard to the market of healthy food delivery in Moscow, it began its development since 2006 which also suggests the existence of prospects and opportunities for finding a niche there to implement various projects. In general, there are three price segments here - high, medium, and low. New market players usually focus on the middle and lower price segments. To get a precise idea about each price segment, turn to the research results of the company "Royal diet."

Statistics shows that the competition in the segment of high prices is the lowest, however entry barriers, in this segment are pretty high and do not allow start-up companies to develop in this segment. Such barriers can be attributed to the high costs of marketing policy, rent rates and delivery. These services are enjoyed by people with real financial freedom and capacity, indicating their abilities for long-term investments in the product acquisition. The number of regular customers, in this case, would be the highest and most steady. It is important to note that the consumer here appreciates quality and efficiency in the first place rather than the cost of production. Regarding the average price segment, the highest competition is here, but the number of consumers is equally high. Prices are focused on consumers of average wage levels and range from RUR 2000 to 4000. At the same time, the consumers in this category are actively changing, so it is constantly required to create promotions, introduce loyalty programs that are hugely time and money consuming. Low price segment is characterized by the lowest costs for the implementation of the project, but there are some complications too. In order to occupy this segment, one must use loyalty programs for their customers, while maintaining quality on a certain level. It is also important to note that low price segment is also characterized by a small number of consumers, since the services of this segment are not particularly attractive due to the low quality of the product. At the moment there are several leading companies in the market for the healthy diet delivery in Moscow. Table 1 lists the main indicators of the most successful participants of this market.

Table 1. Characteristics of the major competitors in the market of healthy food delivery

\begin{tabular}{|c|c|c|c|c|c|}
\hline Company & GrowFood & EasyMeal & JustFood & Just for you & EatBit \\
\hline Foundation year & 2015 & 2012 & 2015 & 2006 & 2016 \\
\hline Start up budget & RUR 130000 & $\begin{array}{l}\text { RUR } \\
1500000\end{array}$ & $\begin{array}{l}\text { RUR } 120 \\
000\end{array}$ & USD 500000 & $\begin{array}{l}\text { RUR } \\
100000 \\
0\end{array}$ \\
\hline $\begin{array}{l}\text { Price segment } \\
\text { RUR/day }\end{array}$ & $\begin{array}{l}\text { Low- } 660 \text { up } \\
\text { Average - } \\
2000-4000\end{array}$ & $\begin{array}{l}\text { Low - } 1300 \\
\text { Average - } \\
2000-4000\end{array}$ & $\begin{array}{l}\text { Low - } \\
1090\end{array}$ & $\begin{array}{l}\text { Average - } \\
2000 \\
\text { High - 4000- } \\
5000\end{array}$ & $\begin{array}{l}\text { Low - } \\
1160\end{array}$ \\
\hline
\end{tabular}




\begin{tabular}{|l|l|l|l|l|l|}
\hline $\begin{array}{l}\text { Average bill per } \\
\text { month, RUR }\end{array}$ & 17600 & 60000 & 32000 & 90000 & 35000 \\
\hline $\begin{array}{l}\text { Average monthly } \\
\text { income, RUR }\end{array}$ & 16000000 & 35000000 & $\begin{array}{l}12800 \\
000\end{array}$ & 72000000 & $\begin{array}{l}14000 \\
000\end{array}$ \\
\hline $\begin{array}{l}\text { Average amount } \\
\text { of customers per } \\
\text { month, persons }\end{array}$ & 800 & $700-800$ & 400 & 1000 & 400 \\
\hline
\end{tabular}

Source: compiled by the authors.

Table 2 gives the comparative analysis of the competitors' market basing on the main criteria: the number of programs, program objectives, frequency of delivery, delivery costs.

Table 2. Data on the major competitors of the healthy food delivery market in Moscow

\begin{tabular}{|c|c|c|c|c|c|}
\hline Company & GrowFood & EasyMeal & JustFood & Justforyou & EatBit \\
\hline $\begin{array}{l}\text { Amount of } \\
\text { programs }\end{array}$ & 4 & 6 & 9 & 15 & 5 \\
\hline Programs & $\begin{array}{l}\text { - weight } \\
\text { management } \\
\text { for athletes }\end{array}$ & $\begin{array}{l}\text { - weight } \\
\text { management } \\
\text { - vegetarianism } \\
\text { - meals for gastritis } \\
\text { - fasting }\end{array}$ & $\begin{array}{l}\text { - weight } \\
\text { management }\end{array}$ & $\begin{array}{l}\text { - weight management } \\
\text { - vegetarianism } \\
\text { - detox } \\
\text { - fasting } \\
\text { Individual menu }\end{array}$ & $\begin{array}{l}\text { weight } \\
\text { managemen } \\
t \text { for athletes }\end{array}$ \\
\hline $\begin{array}{l}\text { Delivery } \\
\text { frequency }\end{array}$ & $\begin{array}{l}2-3 \\
\text { times/week. }\end{array}$ & Daily & 4 times/week. & Daily & Daily \\
\hline $\begin{array}{l}\text { Delivery } \\
\text { costs, RUR. }\end{array}$ & $\begin{array}{l}\text { Free within } \\
\text { Moscow }\end{array}$ & 300 & $\begin{array}{l}\text { Free within } \\
\text { Moscow and } \\
\text { Moscow region } \\
\text { ( } 7 \mathrm{~km} \text { from } \\
\text { Moscow circle } \\
\text { road) }\end{array}$ & $\begin{array}{l}\text { Free within Moscow, } \\
\text { beyond Moscow } \\
\text { circle road } 30 \text { RUR } \\
/ 1 \mathrm{~km} \text { (under } 35 \mathrm{~km} \text { ), } \\
\text { over } 35 \mathrm{~km}-40 \text { RUR }\end{array}$ & $\begin{array}{l}\text { Free within } \\
\text { Mosco }\end{array}$ \\
\hline
\end{tabular}

Source: compiled by the authors.

In the light of this analysis, it is worth noting the features of competitors, enabling them to occupy the position of the market leaders. Table 3 presents the main goals of people using service delivery of healthy nutrition. According to the stated purposes the companies form packages programs for implementing the business.

Table 3. Delivering healthy food companies`customer targets

\begin{tabular}{|l|l|}
\hline \multicolumn{1}{|c|}{ Targets } & \multicolumn{1}{c|}{ Description } \\
\hline Attaining good shape & $\begin{array}{l}\text { People are actively involved in sports and need the right balanced } \\
\text { menus, given their characteristics and preferences }\end{array}$ \\
\hline Preventive treatment & $\begin{array}{l}\text { Clients trust professional dieticians in drawing up their menu. } \\
\text { Consumers are confident that they will be provided with a diet with the } \\
\text { necessary set of macro-and microelements }\end{array}$ \\
\hline $\begin{array}{l}\text { Compliance with proper } \\
\text { nutrition and shortage } \\
\text { of time }\end{array}$ & $\begin{array}{l}\text { The purpose of the consumer is to eat properly, avoiding the } \\
\text { consumption of foods high in sugar, salt, fat, oils. The time limit does } \\
\text { not allow them to independently provide themselves with such food }\end{array}$ \\
\hline Keeping fit & $\begin{array}{l}\text { People have enough time, however, they have no professional } \\
\text { knowledge to develop a balanced diet }\end{array}$ \\
\hline
\end{tabular}

Source: compiled by the authors.

Thus, on the basis of this analysis, the following conclusions can be drawn. Firstly, the market of healthy eating is at the stage of active development. It is not saturated, and therefore the possibility of successful implementation of business ideas is high. Secondly, among the existing trends the most relevant are: the development of vegetarianism, trends for weight management, healthy lifestyle, the formation of a balanced diet. The companies are actively using mobile applications and social networking to advertise their products. Thirdly, the main competitors were identified and considering their peculiarities there have been selected the most promising pricing and consumer segments for the realization of the project. The analysis has shown that it is advisable to start implementing the ideas in the average price segment, focusing on the following consumers: professional athletes, people who want to lose weight, gain weight, as well as vegetarians. The average price segment is the most promising and preferred because, despite high competition, it is characterized by a large and diverse number of consumers.

Table 4 presents the results of the calculation of the break-even point, or a critical volume of production, which is determined by dividing permanent total costs by profit margins per 1 unit of production, as well as margin of safety which is calculated by deducting critical volume from the actual production. 
Table 4. (Break-even point) Critical volume calculation and Company efficiency calculation

\begin{tabular}{|l|l|l|l|}
\hline \multicolumn{1}{|c|}{ Year } & \multicolumn{1}{c|}{$\mathbf{2 0 1 8}$} & \multicolumn{1}{c|}{$\mathbf{2 0 2 0}$} \\
\hline $\begin{array}{l}\text { Critical volume per } \\
\text { year }\end{array}$ & 4200,9 & 5451,3 & 6173,6 \\
\hline $\begin{array}{l}\text { Actual production per } \\
\text { year }\end{array}$ & 4320 & 7200 & 10800 \\
\hline Margin of safety & $+119,1$ & $+1748,7$ & $+4626,4$ \\
\hline $\begin{array}{l}\text { Company efficiency, } \\
\%\end{array}$ & 1,4 & 19,3 & 36,6 \\
\hline
\end{tabular}

Source: compiled by the authors.

Overall profitability of the organization, calculated through dividing the total profits of the company by the total costs. In order to determine whether the company's profitability is high or low, it is necessary to compare it with the average profitability in the industry for this type of activity. Calculations show that in the third year of existence on the market the company can have the profitability of $36.6 \%$, which is a good indicator in comparison with average market prices indicators. The average profitability of companies with the same service, ranges from 20 to $60 \%$

\section{Conclusion}

While calculating the financial results of the company "FoodGoodFit" it is predicted that after three years the company's revenue will increase by 2.5 times. We can assume that the business will have a high rate of development that would lead to a tangible increase in revenues and strengthen the position of the company "FoodGoodFit" among the leaders in the category of "healthy eating". Thus, a healthy diet is a fairly popular destination for business development. There are a lot of manufacturers in the market, but big players take up more than $80 \%$ of production. Companies such as "GrowFood" and "Justforyou" occupy a leading position on the market for the delivery of healthy eating. However, despite this fact, the product cannot be called homogeneous. During the execution of the work, it was found that the market for the delivery of healthy nutrition is actively developing particularly in metropolitan areas. This niche is in the stage of formation, the market for the delivery of healthy eating is not saturated. Residents of big cities actively employ this service, generating strong demand and giving opportunity to expand service to deliver healthy food.

\section{References}

1. S. Cai-Juan, R. Ramli, R.A. Rahman, Nutrients requirements and composition in a grouper fish feed formulation. European Proceedings of Social \& Behavioural Sciences EpSBS, 14, 60-66. DOI: 10.15405/epsbs.2016.08.10 (2016).

2. V.E. Korytova, S.A. Garbuz, A.G. Budrin, Research of consumers in the Russian market of healthy food. Humanities, Social and Economic and Social Sciences, 8-9. URL: http://onlinescience.ru/userfiles/file/aez5jnzuc3wfl1bgvdzpuqdpaxxesim8.pdf (2017). [in Rus.].

3. K. Loktev, Doctor "Snickers". How product manufacturers support a healthy lifestyle for consumers. Forbes. URL: http://www.forbes.ru/biznes/348929-doktor-snikers-kak-proizvoditeli-produktov-podderzhivayut-zdorovyy-obrazzhizni (2017). [in Rus.].

4. L. Manea, G. Epuran, The impact of advertisements for Romanian food products on consumers. European Proceedings of Social \& Behavioural Sciences EpSBS, 15, 530-544. DOI: 10.15405/epsbs.2016.09.68 (2016).

5. V.V. Ragozin, T.B. Golubeva, Nutrition of the inhabitants of the megalopolis: the results of a sociological study. Rational Nutrition, Food Additives and Biostimulants, 1, 28-31 (2018). [in Rus.].

6. A. Voronoi, P. Manko, E. Yakovleva, Review of the market of sports nutrition in the city of St. Petersburg. Marketing Encyclopedia. URL: https://www.marketing.spb.ru/mr/food/sport_02.htm (2003). [in Rus.].

7. Rosstat, Federal State Statistics Service. Health care. Retrieved from: http://www.gks.ru/wps/wcm/connect/rosstat_main/rosstat/ru/statistics/population/healthcare/\#. $\quad$ Accessed: 21.11.2018 (2018). [in Rus.].

8. O.V. Astafeva, E.V. Astafiev, The issues of ensuring food security for the sustainable development of the country. Economy. Business. Banks, 4(21), 39-50 (2017). [in Rus.]. 